\title{
Belka czy płyta? Klasyfikacja elementów konstrukcyjnych w świetle teorii wytrzymałości materiałów oraz literatury inżynierskiej
}

\author{
Marcin Samborski, Marta Slowik \\ Katedra Konstrukcji Budowlanych, Wydziat Budownictwa i Architektury, Politechnika Lubelska, \\ e-mail:m.samborski@pollub.pl,m.slowik@pollub.pl
}

Streszczenie: Podstawą kategoryzacji belek i płyt w konstrukcjach żelbetowych są elementy prętowe i powłokowe zdefiniowane w ramach teorii wytrzymałości materiałów. Niejednoznaczność definicji belki i płyty, podawanych w literaturze inżynierskiej, może prowadzić do nieprawidłowego określenia rozkładu naprężeń w elementach żelbetowych.

Słowa kluczowe: belka, płyta, definicja pręta, definicja powłoki, rozkład naprężeń.

\section{Wprowadzenie}

Klasyfikacja podstawowych elementów konstrukcyjnych pracujących na zginanie obejmuje podział na płyty, belki oraz tarcze. W niniejszym artykule, pominięto rozważania dotyczące słupów, ścian i konstrukcji blokowych.

Definicje, według których dokonywano podziału na belki, płyty i tarcze wynikają z opisu elementów prętowych i powłokowych zawartych w teorii wytrzymałości materiałów. Zapisy dotyczące tych elementów podane w literaturze inżynierskiej ulegały zmianom na przestrzeni ostatnich lat w zależności od aktualnie obowiązujących norm, co spowodowało brak jednoznacznie określonej definicji płyty i belki spójnej z modelami przyjmowanymi w teorii wytrzymałości materiałów.

Prawidłowe zakwalifikowanie elementu konstrukcyjnego może mieć istotne znaczenie przy określeniu rozkładu naprężeń, a w konsekwencji przy wymiarowaniu przekrojów i doborze zbrojenia.

\section{Definicja pręta i powłoki według teorii wytrzymałości materiałów}

\subsection{Definicja pręta}

Według najczęściej spotykanej definicji w literaturze [4,5], prętem jest obiekt, którego jeden wymiar (długość) jest znacznie większy od dwu pozostałych wymiarów (szerokość i wysokość przekroju poprzecznego). W rozumieniu geometrycznym, pręt powstaje w wyniku śladu ruchu pewnej figury płaskiej. Środek pola tej figury (oznaczony jako C na Rys. 1) porusza się w zależności od kształtu pręta po linii prostej lub zakrzywionej (np. pręt odkształcony). Linia ta wyznacza tym samym oś pręta. Figura tworząca kształt pręta nazywana jest przekrojem poprzecznym. Pręty o przekroju stałym nazywamy prętami pryzmatycznymi.

Ze względu na ogólny charakter granicznych wymiarów elementu prętowego, można przeprowadzić opis elementu przy użyciu poniższej procedury. Jeśli w przekroju poprzecznym pręta oznaczymy środek (leżący na jego osi), jako punkt C, to stosunek maksymalnej 
odległości od środka przekroju do obwodu pręta do jego rozpiętości w osiach podparć jest dużo mniejszy od jednego, to element ten należy uznać za pręt - Rys. 1. Przez pojęcia dużo mniejszy od jednego rozumieć należy wartość rzędu jednej dziesiątej.

W najbardziej ogólnym zapisie definicję tę można podać, jako warunek:

$$
\lim _{\text {sup }}\left(\frac{d_{(i)}}{l}\right) \ll 1
$$

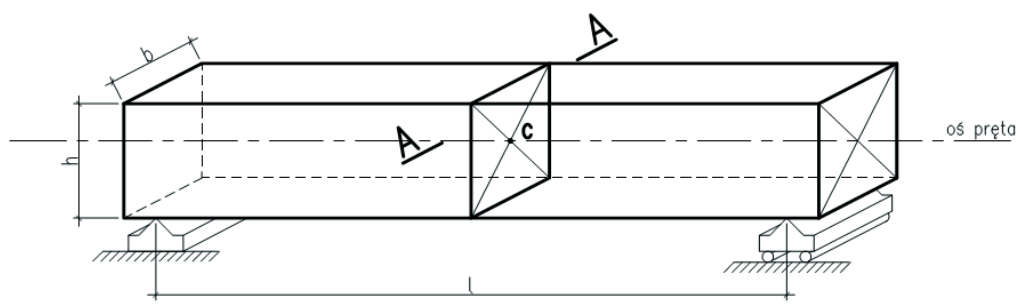

PRZEKROJ A-A

Rys. 1. Element prętowy

\subsection{Definicja powloki}

Powłoki należą do szerokiej grupy ustrojów powierzchniowych. Elementy te definiowane są w literaturze, np. [6], jako ciała, w których jeden z wymiarów (grubość) jest znacznie mniejszy od pozostałych. W ustrojach powierzchniowych wyróżnić można powierzchnię górną, dolną (lub zamiennie powierzchnia zewnętrzną i wewnętrzną) i boczną. W przypadku ustrojów powierzchniowych, rolę osi pełni tzw. powierzchnia środkowa, równoodległa od powierzchni górnej i dolnej. W tym rozumieniu, wysokość (grubość) przekroju jest najkrótszą odległością pomiędzy powierzchnią górną i dolną, odmierzoną wzdłuż prostej normalnej do powierzchni środkowej.

Uszczegóławiając klasyfikację ustrojów powierzchniowych, element, w którym powierzchnia środkowa jest płaszczyzną nazywamy płytą. Powłoką natomiast jest element o powierzchni środkowej zakrzywionej. Do opisu powłok wprowadzono określenie cienkiego ustroju powierzchniowego, dla którego zachodzi nierówność:

$$
\frac{h}{l} \ll 1
$$

gdzie $l$ - to charakterystyczna długość odmierzana na powierzchni środkowej, $h$ - wysokość przekroju. Długość może być opisywana różnie, dla przykładu: w płytach prostokątnych:

$$
l=a, \quad a<b, \quad \frac{h}{a}<\frac{1}{10}
$$

W przypadku powierzchni zakrzywionych o głównych promieniach krzywizny $R_{l}$ i $R_{2}$ ustrój będzie cienki, jeśli zachodzi nierówność:

$$
\frac{h}{R_{\min }}<\frac{1}{20} \div \frac{1}{30}
$$

gdzie $R_{\min }$ - minimalny promień krzywizny. W wyniku przyjęcia takiej definicji ustroju powierzchniowego, wszystkie rozważania będą odnoszone do powierzchni środkowej, 
a współrzędne opisujące element $x, y$, sprowadzą ustroje do zadania dwuwymiarowego. Dlatego w przypadku ustrojów, w których grubość jest porównywalna z pozostałymi wymiarami, opis dwuwymiarowy może prowadzić do rozbieżności w porównaniu z opisem trójwymiarowym.

Najbardziej ogólną definicję elementu powłokowego można przedstawić następująco:

$$
\lim _{\text {sup }}\left(\frac{h}{l}\right) \ll 1
$$

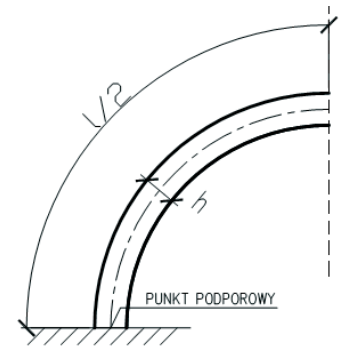

Rys. 2. Fragment elementu powłokowego

\subsection{Rozkład naprężeń w elemencie zginanym według teorii sprężystości}

Charakter odkształcenia się elementu poddanego zginaniu został opisany w [4] na przykładzie elementu przedstawionego na rysunku 3, obciążonego momentami skupionymi na jego końcach, powodującymi pojawienie się czystego zginania. W wyniku przyłożonego obciążenia, siatka ulegnie odkształceniu według schematu na rysunku 4.

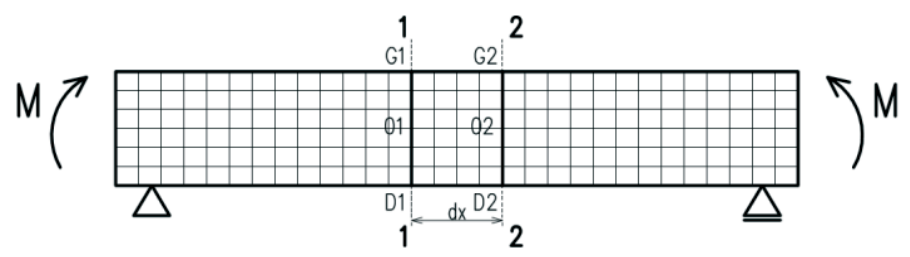

Rys. 3. Element prętowy (belkowy) z teoretyczną siatką przed odkształceniem

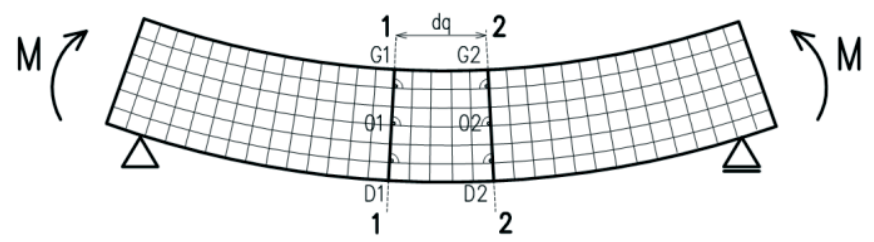

Rys. 4. Element prętowy (belkowy) z teoretyczną siatką po odkształceniu leżności:

Na podstawie analizy powyższego przykładu można zaobserwować następujące za-

- Linie podłużne siatki zarówno przed, jak i po odkształceniu pozostają do siebie równoległe;

- Linie poprzeczne siatki po odkształceniu nachyliły się względem siebie, ale nadal pozostały proste i prostopadłe do zakrzywionych linii podłużnych, w związku z czym można założyć, że przekroje poprzeczne wyznaczone przez te linie są pła- 
skie po odkształceniu. Obserwacja jest zgodna z założeniem płaskich przekrojów;

- W przypadku zginania czystego, kąty zawarte między liniami podłużnymi i poprzecznymi są proste. Oznacza to, że w elemencie nie doszło do odkształcenia postaciowego;

- Linia podłużne siatki od strony wypukłej (odcinek D1D2) uległy wydłużeniu, natomiast od strony wklęsłej (G1G2) - skróceniu.

Rozważany przykład umożliwia wyciągnięcie następujących wniosków:

- Odkształcenia włókien zmieniają się na wysokości przekroju w sposób ciągły. Oznacza to, że można wyznaczyć włókna na pewnej wysokości, które zachowały swoje pierwotne długości (odcinek O1O2). Powierzchnia przecinająca te włókna oddziela strefę ściskaną od rozciąganej i jest nazywana powierzchnią obojętna, natomiast odcinek $\mathrm{O} 1 \mathrm{O} 2$ - śladem powierzchni obojętnej;

- W myśl założenia, że pręt jest symetryczny w płaszczyźnie działającego obciążenia, odkształcenia na obu końcach są takie same. Wynika z tego wniosek, że odkształcenia na powierzchni równoległej do powierzchni obojętnej nie zależą od położenia na szerokości elementu;

- Ponieważ obroty poszczególnych przekrojów odbywają się względem ich osi obojętnych, leżących na powierzchni obojętnej, to odcinek O1O2 również znajduje się na powierzchni obojętnej i zachowuje swoją długość pierwotną po odkształceniu;

- Płaska powierzchnia obojętna przed odkształceniem staje się powierzchnią walcową po odkształceniu,

Analiza zginania z udziałem sił poprzecznych przysparza wiele problemów, dlatego też przyjmuje się, że wystarczająco dokładnym przybliżeniem jest rozpatrywanie zginania ze ścinaniem, jako stan, w którym zginanie traktowane jest, jako zginanie czyste, natomiast ścinanie jest uwzględniane pośrednio, jako naprężenia i odkształcenia wywołane siłami poprzecznymi [4].

Podłużne włókna pręta przy czystym zginaniu nie naciskają na siebie w związku, z czym możemy je traktować, jako pojedyncze pręty rozciągane lub ściskane osiowo. Zakładając, że moduł sprężystości materiału E jest jednakowy dla ściskania i rozciągania osiowego, a zginanie działa w zakresie proporcjonalności, można zastosować prawo Hooke’a. Wartość naprężenia normalnego wyniesie wtedy:

$$
\sigma=\frac{E z}{\rho}
$$

gdzie $\rho$ - promień krzywizny powierzchni obojętnej, $z$ - odległość od osi obojętnej przekroju, $E$ - współczynnik sprężystości podłużnej.

Wartość naprężeń normalnych zmienia się liniowo na wysokości belki. Osiąga wartość zero na osi obojętnej oraz wartości maksymalne w najbardziej oddalonych od osi obojętnej punktach przekroju [4]. W wyniku przekształceń równań równowagi przekroju z sumy rzutów sił, finalnie wartość naprężenia normalnego można uzależnić od działającego momentu zginającego i przedstawić go w postaci:

$$
\sigma=\frac{M_{\alpha} z}{J_{y}}
$$

gdzie $M_{\alpha}$ - wartość zewnętrznego momentu zginającego, $J_{y}$ - moment bezwładności przekroju belki względem osi obojętnej, $z$ - odległość od osi obojętnej do punktu, w którym obliczane jest naprężenie. 
Rozkład naprężeń normalnych przedstawiono na rysunku 5.

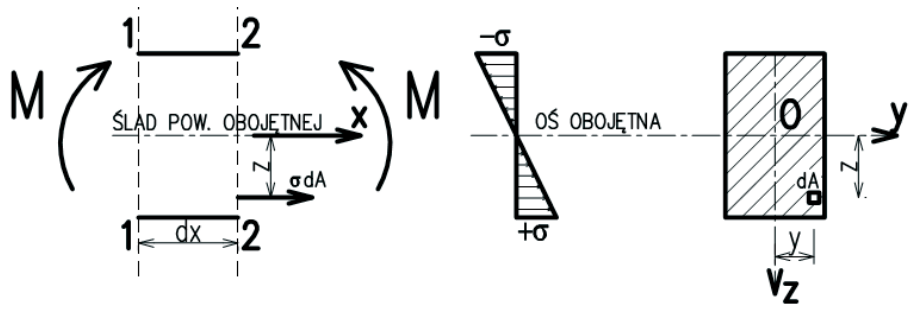

Rys. 5. Rozkład naprężeń normalnych w przekroju pręta (belki) przy czystym zginaniu

Udział naprężeń stycznych, wywołanych siłami poprzecznymi prowadzi do tzw. deplanacji (spaczenia) przekroju, przez wywołanie odkształcenia postaciowego (zaburzenie kątów siatki na elemencie) naruszającego założenie płaskich przekrojów. Jest to jednak efekt uwzględniany tylko dla prętów cienkościennych. Istotnym faktem jest, że naprężenia normalne, dla zginania ze ścinaniem, można wyznaczyć w oparciu o założenia czystego zginania tylko dla elementów prętowych, w których rozpiętość przekracza, co najmniej pięciokrotnie jej wysokość [4]. Pomiędzy siłą poprzeczną, a wywołaną przez nią naprężeniami istnieje zależność opisana wzorem:

$$
V_{\alpha}=\int_{A} \tau_{x z} d A
$$

gdzie $\tau_{x z} \mathrm{~d} A$ - elementarna siła styczna, równoległa do wywołującego je wektora siły poprzecznej $V_{\alpha}$, działającego na elementarne pole $\mathrm{d} A$

Ponadto zachodzi równość:

$$
\tau_{x z}=\tau_{z x}
$$

Rozkład naprężeń stycznych przedstawia rysunek 6.
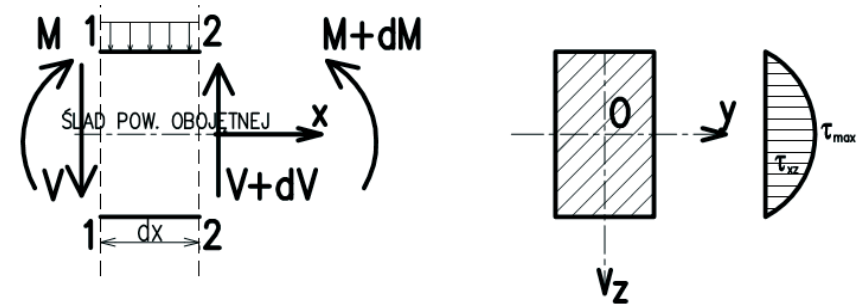

Rys. 6. Rozkład naprężeń stycznych w przekroju poprzecznym belki pracującej pod obciążeniem ciągłym

Należy zaznaczyć, że założenie równomiernego rozkładu naprężeń stycznych na szerokości elementu prętowego (belki), równolegle do osi obojętnej przekroju poprzecznego, jest poprawne tylko dla ustrojów wąskich i wysokich, prostokątnych (mały stosunek $b / h$ ). W ogólnym przypadku rozkład naprężeń stycznych na szerokości przekroju jest nierównomierny, w taki sposób, że naprężenia są większe przy krawędziach pionowych, mniejsze w środku, a różnica ta wzrasta wraz ze zwiększaniem stosunku $b / h$.

Modele obliczeniowe wykorzystywane w teorii wytrzymałości materiałów (elementy prętowe i powłokowe) są podstawą do klasyfikacji konstrukcji żelbetowych w praktyce 
inżynierskiej. W wyniku tego, elementy prętowe odpowiadają konstrukcjom belkowym (podciągi, nadproża, oraz pozostałe belki żelbetowe), a elementy powłokowe - konstrukcjom płytowym i powłokowym (płyty stropowe monolityczne, powłoki żelbetowe zbiorników). Przejście z modelu teorii wytrzymałości materiałów na obliczeniowy model konstrukcyjny powoduje pojawienie się rozbieżności w rozkładzie naprężeń dla poszczególnych modeli. W rozdziale 3.3 scharakteryzowano rozkład naprężeń w zginanym przekroju żelbetowym według założeń przyjmowanych przy wymiarowaniu konstrukcji z betonu.

\section{Definicja belki i płyty w odniesieniu do elementów żelbetowych}

\subsection{Definicja belki}

Przed wprowadzeniem norm europejskich, definicje elementów kształtowane były przepisami PN-B-03264:200 [2]. W rozumieniu tych przepisów za belkę uznać można element, którego rozpiętość jest, co najmniej dwu i półkrotnie większa od wysokości przekroju. Definicja belki w rozumieniu klasycznym (belki niskiej) dotyczy elementów, dla których stosunek rozpiętości efektywnej (w osiach podpór) do jej wysokości jest większy niż cztery. Elementy niespełniające warunku, należy rozpatrywać, jako belki-ściany według teorii tarcz. W normie PN-B-03264 nie podano jednak szczegółowych zaleceń w tym zakresie.

Aktualnie podawany opis zawarty w normie PN-EN 1992-1-1 [1], kwalifikuje element, jako belkę, gdy spełnia zależność opisaną wzorem:

$$
\frac{l}{h}>3
$$

gdzie $l$-rozpiętość belki, $h$ - wysokość przekroju poprzecznego.

Opis belki przedstawiony powyżej, był również stosowany w literaturze [9].

Definicje dotyczące elementów belkowych odnaleziono także w normowych przepisach amerykańskich [8]. Zgodnie z tymi zapisami element konstrukcyjny jest klasyfikowany, jako belka, gdy jego rozpiętość jest większa lub równa 10-krotności wysokości przekroju, a szerokość przekroju poprzecznego stanowi w przybliżeniu połowę wysokości. Zależność opisano wzorem:

$$
\frac{l}{h}>10
$$

gdzie $l$-rozpiętość belki, $h$-wysokość przekroju poprzecznego.

\subsection{Definicja płyty}

Definicja płyty podawana w literaturze technicznej, np. [3], jest niejednoznaczna, a graniczny warunek sprowadza się do tego, że obydwa wymiary w rzucie są większe ,„(...) niż czterokrotna lub pięciokrotna całkowita grubość płyty.”. Brak na ten temat sprecyzowanej definicji w normie PN-B-03264:2002. Zalecenia przytoczone w [3] są zbieżne z wytycznymi podanymi w Eurokodzie 2 [1].

Według definicji zawartych w normie PN-EN 1992-1-1 [1] płyta jest elementem, dla którego wysokość (grubość) przekroju jest, co najmniej pięciokrotnie mniejsza niż minimalny wymiar w rzucie. Warunek ten jest zgodny, co do opisu z literaturą [7]. Zależność opisano poniżej: 


$$
\frac{l_{\min }}{h}>5
$$

gdzie $l_{\min }$ - najmniejsza rozpiętość płyty, $h$-wysokość przekroju poprzecznego.

Wśród konstrukcji płytowych wyróżnia się dodatkowo wewnętrzny podział na płyty jednokierunkowo zbrojone (o momencie zginającym dominującym tylko w jednym kierun$\mathrm{ku}$ ) oraz na elementy dwukierunkowo zbrojone (wartości momentów zginających są zbliżone w obu kierunkach). Zależność dla płyty pracującej dwukierunkowo podaną w [8] opisano wzorem:

$$
0,5 \leq \frac{l_{y}}{l_{x}} \leq 2,0
$$

gdzie $l_{x}, l_{y},-$ wymiary boków płyty.

Płytę należy uznać za jednokierunkowo zbrojoną, jeśli dwa swobodne, niepodparte brzegi płyty są w przybliżeniu równoległe. Jednokierunkowo zbrojone uznawane może być także pasmo płytowe leżące w centralnej części płyty (równoległe do krótszego boku) w przybliżeniu prostokątnej, opartej na czterech krawędziach, w której stosunek długości boków jest większy od dwóch.

Kategoryzacja elementów płytowych według przepisów amerykańskich, podana w [10], obejmuje podział na płyty jedno i dwukierunkowo zbrojone. W pierwszym przypadku, za płytę jednokierunkowo zbrojoną uznaje się element, podparty tylko na dwóch przeciwległych krawędziach lub oparty na wszystkich krawędziach przy stosunku długości boków prostokątnej płyty, co najmniej 2:1. Rozpatrując dalsze zapisy, wywnioskować można, że płyty jednokierunkowo zbrojone traktowane są, jako układ przylegających do siebie belek o szerokości 12' (odpowiada to 30,48 cm). Taki schemat pokazano na Rys. 7.

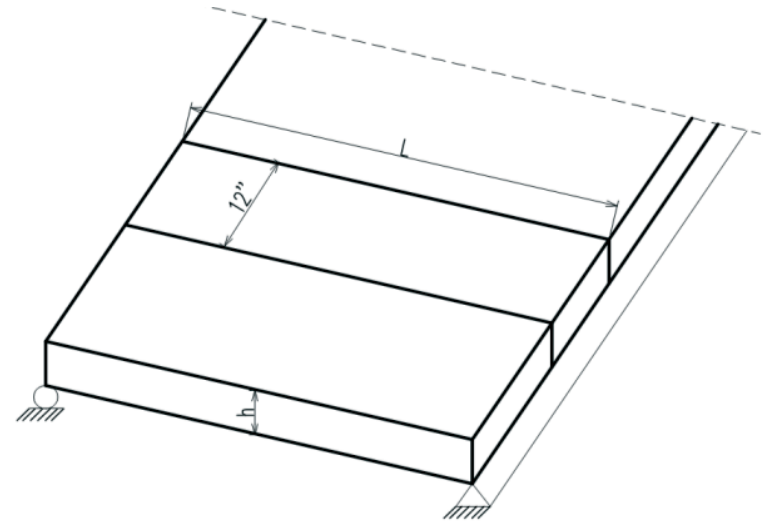

Rys. 7. Schemat płyty jednokierunkowo zbrojonej

\subsection{Rozkład naprężeń w przekroju elementów żelbetowych}

Zapisy zawarte w normie PN-EN 1992-1-1 [1] odnoszą się do pracy żelbetowych elementów zginanych. Dotyczą one wszystkich zginanych elementów żelbetowych, w których nie dochodzi do zmiany kształtu przekroju po obciążeniu (płaskie przekroje przed obciążeniem pozostają w przybliżeniu płaskie po obciążeniu). Poniżej podano założenia dotyczące elementów zbrojonych zwykłą stalą zbrojeniową (bez cięgien sprężających): 
- Płaskie przekroje pozostają płaskie,

- Odkształcenie zbrojenia powiązanego z otaczającym betonem siłami przyczepności w przypadku ściskania i rozciągania jest równe odkształceniu otaczającego je betonu,

- Pomijana jest wytrzymałość betonu na rozciąganie,

- Naprężenia ściskające w betonie wyznacza się na podstawie zależności naprężenieodkształcenie pokazanych na Rys. 8,
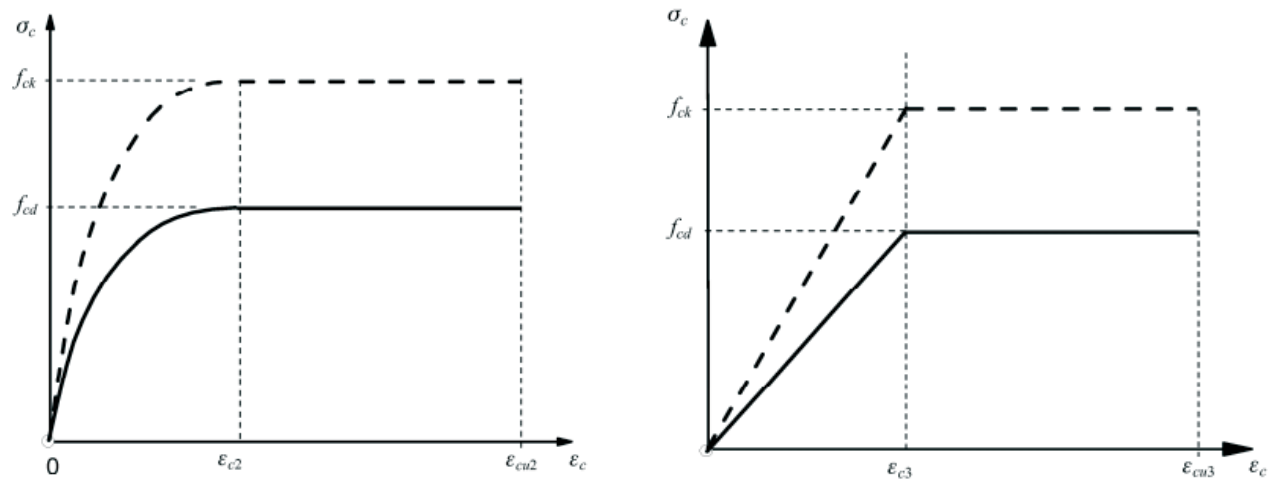

Rys. 8. Zależności naprężenie-odkształcenie w betonie ściskanym, przyjmowane przy wymiarowaniu

- Naprężenia w stali zbrojeniowej wyznacza się na podstawie zależności przedstawionych na Rys. 9.

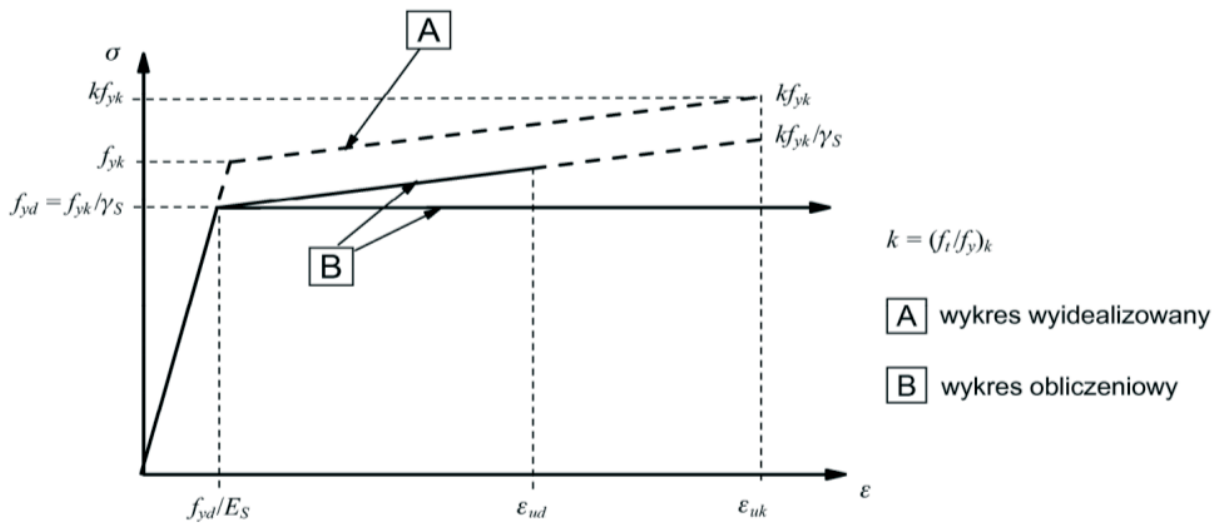

Rys. 9. Zależności naprężenie-odkształcenie w stali zbrojeniowej przyjmowane przy wymiarowaniu

Zapisy zawarte w Eurokodzie 2 [1] wskazują, że do obliczeń można przyjąć zależność paraboliczno-prostokątną wykresu naprężenie-odkształcenie betonu. Dopuszcza się jednak stosowanie innych uproszczeń, pod warunkiem, że są one równoważne z pierwszą zależnością lub znajdują się po stronie bezpiecznej.

Rozkład naprężeń dla zależności paraboliczno-prostokątnej i bilinearnej przyjmowany do wymiarowania konstrukcji żelbetowych przedstawiono na Rys. 10. 


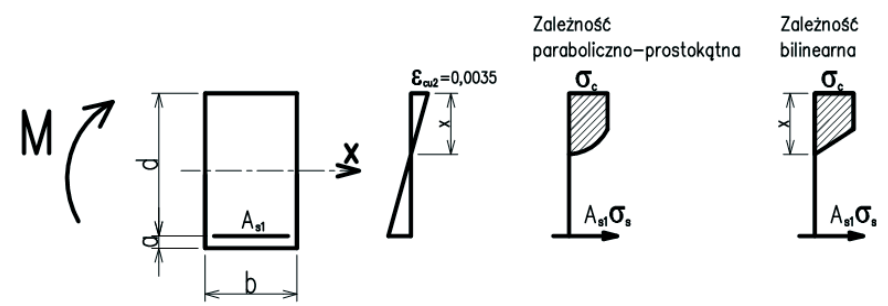

Rys. 10. Rozkład odkształceń i naprężeń w przekroju żelbetowym

Należy zauważyć, że w wyniku przyjętych założeń do wymiarowania elementów żelbetowych na zginanie, rozkład naprężeń nieco odbiega od teoretycznego rozkładu w modelu zaczerpniętym $\mathrm{z}$ teorii wytrzymałości materiałów. Rozkład naprężeń normalnych w przekroju betonowym przyjmuje odtąd formę paraboliczno-prostokątną lub w uproszczeniu - prostokątną, a ze względu na pominięcie wytrzymałości betonu na rozciąganie wartości naprężeń rozciągających przejmuje w całości zbrojenie rozciągane (przedstawione w postaci siły wypadkowej). Istotną zależnością jest zachowanie płaskich przekrojów zarówno w modelu przyjmowanym w teorii wytrzymałości materiałów jak i przy wymiarowaniu konstrukcji.

\section{Podsumowanie}

Przeprowadzone studia literaturowe wskazują, że brak jest jednoznacznej i powszechnie obowiązującej definicji belki i płyty. Prawidłowe zakwalifikowanie elementu konstrukcyjnego do grupy belek lub płyt ma decydujące znaczenie przy konstruowaniu zginanych elementów żelbetowych.

Rozkład naprężeń normalnych w elemencie przy jednoczesnym działaniu momentu zginającego i sił poprzecznych, zgodnie z założeniami teorii wytrzymałości materiałów jest wyznaczany jak w przypadku czystego zginania. Podejście to jest poprawne w przypadku smukłych elementów prętowych, w których rozpiętość przekracza, co najmniej pięciokrotnie jej wysokość. Jednocześnie równomierny rozkład naprężeń stycznych na szerokości przekroju ma miejsce jedynie w przypadku wąskich przekrojów (o małym stosunku szerokości do wysokości). W ogólnym przypadku, rozkład naprężeń stycznych odbiega od równomiernego, a różnice wzrastają ze zwiększaniem wartości stosunku szerokości do wysokości. Maksymalne wartości naprężeń stycznych osiągane są na krawędziach pionowych, minimalne w środku przekroju. Zatem proporcje wymiarów w elemencie konstrukcyjnym mogą wpływać na rozkład naprężeń, co determinuje sposób kształtowania zbrojenia w belkach i płytach żelbetowych.

Metoda wyznaczania sił wewnętrznych, rozkład naprężeń i wymiarowanie miarodajnych przekrojów powinny być dostosowane do rodzaju elementu. Zagadnienie poprawnego rozróżnienia płyt i belek wymaga dalszych analiz.

\section{Literatura}

1. PN-EN 1992-1-1:2008/NA: 2010 Eurokod 2: Projektowanie konstrukcji z betonu Część 1-1: Reguły ogólne i reguly dla budynków.

2. PN-B-03264:2002: Konstrukcje betonowe, żelbetowe i sprężone, obliczenia statyczne i projektowanie. 
3. Janowski Z., Chudyba K. Ksztaltowanie plyt, belek i stupów, [w]: Konstrukcje betonowe, żelbetowe $i$ sprężone. Instytut Techniki Budowlanej, Warszawa 2005. ISBN 83-7413-651-0, s. 245-282.

4. Jastrzębski P., Mutermilch J., Orłowski W. Wytrzymałość materiałów. Część 1. Arkady, Warszawa 1985.

5. Walczak J. Wytrzymałość materiałów oraz podstawy teorii sprężystości i plastyczności. Tom I. PWN, Warszawa 1973.

6. Waszczyszyn Z., Radwańska M. Ustroje powierzchniowe. PK, Kraków 1985.

7. Knauff M. Obliczanie konstrukcji żelbetowych wedtug Eurokodu 2. Wyd. 1. Wydawnictwo Naukowe PWN, Warszawa 2012. ISBN: 978-83-01-17023-3

8. Łapko A., Bjarne Ch. J. Podstawy projektowania i algorytmy obliczeń konstrukcji żelbetowych. Wydawnictwo Arkady, Warszawa 2005. ISBN: 83-213-4397-X.

9. Starosolski W. Konstrukcje żelbetowe wedtug Eurokodu 2 i norm zwiazanych. Tom 5. Wydawnictwo Naukowe PWN, Warszawa 2016. ISBN: 978-83-01-18476-6.

10. McCormac J.C., Nelson J.K. Design of Reinforced Concrete ACI 318-05 Code. Wyd. 7. GGS Book Services, Atlantic Highlands 2006. ISBN 0-471-76132-X.

\title{
A beam or a slab? \\ Classification of structural members according to the theory of solid mechanics and engineering literature
}

\author{
Marcin Samborski, Marta Slowik \\ Lublin University of Technology, Faculty of Civil Engineering and Architecture, \\ e-mail:m.samborski@pollub.pl,m.slowik@pollub.pl
}

\begin{abstract}
The basic solid mechanics definition of a bar-type member and a shell-type member gives rules for the classification of structural reinforced concrete members on beams and slabs. But the definition of a beam and a slab, which we can find in an engineering literature, are not precise and this fact can lead to the incorrect determining of stress distribution in reinforced concrete members.

Keywords: slab, beam, definition of a bar-type member, definition of a shell-type member, stress distribution.
\end{abstract}

